\title{
Job Satisfaction As A Mediation Variable Between The Influence Of Transformational Leadership And Organizational Climate On Organizational Citizenship Behavior (Ocb) In Regional Drinking Water Company District Of Cilacap
}

\author{
Alfato Yusnar Kharismasyah ${ }^{1}$, Yudhistira Pradipta, ${ }^{2,}$ Toufan Aldian syah ${ }^{3}$ \\ \{chipatoyusnar@gmail.com ${ }^{1}$,yudistirapradhipta@ump.ac.id ${ }^{2}$,toufan.aldiansyah86@gmail.com ${ }^{3}$ \} \\ Economics and Bussines Faculty ${ }^{1}$, Universitas Muhammadiyah Purwokerto ${ }^{2}$, Ph.D. Student \\ Economics and Bussines Faculty IAIN Purwokerto ${ }^{3}$
}

\begin{abstract}
This research aims to analyze and explain job satisfaction as a mediation variable between the effect of transformational leadership and organizational climate on organizational citizenship behavior employees of Regional Drinking Water Company Tirta Wijaya Cilacap regency. This research uses a quantitative approach. The sampling technique uses purposive sampling method and Slovin formula. This research uses a questionnaire with the number of respondents 131 permanent employees of Regional Drinking Water Company Tirta Wijaya Cilacap Regency. Data analysis uses validity test, classic assumption test, multiple linear regression test, coefficient of determination test, t-test $\mathrm{f}$ test, and Sobel test to analyze the indirect effect of each variable. The results of the research show that job satisfaction variables can be a mediation between the influence of transformational leadership and organizational climate on organizational citizenship behavior. So the company must increase the variables that can affect OCB in order to create company goals. This research also suggests further research to add other variables not examined to strengthen the relationship of each variable with organizational citizenship behavior.
\end{abstract}

Keywords: Transformational leadership, organizational climate, job satisfaction and organizational citizenship behavior.

\section{Introduction}

Water is a vital requirement for human life. Its availability is crucial. Its use is not only limited to household needs but also for the public, social and economic facilities. Indonesia, as an independent nation has regulated the use of water contained in the territory of Indonesia, which is regulated in the 1945 Constitution Article 33 paragraph (3) which reads "Water and natural resources contained therein are controlled by the state and used for the greatest prosperity of the people. "Seeing that regarding the management system and drinking water supply is the responsibility of the government.

To achieve an equitable supply of clean water is not an easy thing; adequate facilities and infrastructure are needed as well as competent human resources (HR). HR plays a significant role in a company to achieve company goals because it needs employees who can work beyond their duties and provide performance beyond what is expected or another role. This another role outside of the job description, another role from the job description; this is called 
organizational citizenship behavior. Although it is not a formal work obligation for an employee, organizational citizenship behavior effectively supports the organization's functioning. Moreover, successful organizations need employees who will act beyond their general work duties and positively affect the employee and the Organization [23]

In this research regarding the management of clean water supply, the object chosen by the researcher was the Tirta Wijaya Regional Drinking Water Company, Cilacap Regency, which is a Regional Owned Enterprise. Regional drinking water Company has the main task of carrying out water management where the amount of clean water is increasingly needed along with the increasing number of customers, and this requires the company to be able to maximize its employees so that it is effective and efficient so that it is able to provide optimal service for its customers. Based on interviews conducted by researchers to the human resource department, there are problems regarding organizational climate where some employees complain that they have to adapt again to the work environment and their co-workers are assigned, because frequent transfer of tasks affects the behavior and quality of organizational citizenship behavior.

Transformational leadership defines leaders who inspire their followers to transcend their interests and have the ability to have a profound and extraordinary influence on their followers [21]. Leaders who apply this type of transformational leadership will tend to encourage their followers to produce work beyond what is expected by changing their vision, setting an example, giving support, and stimulating a desire to change for the better [21].

An excellent organizational climate can provide comfort to work even if they will survive and be loyal to the company. Employees will be more productive in carrying out tasks by voluntarily performing extra-role behaviors or organizational citizenship behavior without expecting any reward. However, based on interviews conducted by researchers to the human resources department, there are problems regarding the organizational climate. Some employees complained about having to adapt again to the work environment and their work colleagues assigned because the frequent transfer of tasks affects the behavior and quality of employee performance.

In addition to the variables mentioned above, job satisfaction can also influence organizational citizenship behavior. That satisfied employees are more likely to talk positively about the organization, help others, and far exceed rational expectations [23]. Employees who are satisfied with the job and the company where they are located will do positive things for the company and colleagues because of wanting to reciprocate what they have been getting from the company [23].

Research on Organizational Citizenship Behavior has previously been conducted. However, there is still a research gap, which is known that there is still some inconsistent research in the results of research. Such as resulting from that transformational leadership influences significantly towards organizational citizenship behavior [1]. However, it was in contrast to the research results which shows that transformational leadership has no significant effect on organizational citizenship behavior [22]. Further research on job satisfaction previously conducted by[7], [28] obtained the result that job satisfaction had a positive and significant effect on organizational citizenship behavior, but in a research conducted by [20] obtained different results. Thus research results that job satisfaction has a negative and not significant effect on organizational citizenship behavior and suggests adding other variables to strengthen the relationship between these variables. Some of these different research results have spurred researchers to try to examine how the influence between transformational leadership and organizational climate on organizational citizenship behavior by positioning 
job satisfaction as a mediating variable, then in this research the following problems were formulated:

1. How does transformational leadership influence job satisfaction?

2. How does the influence of the organizational climate on job satisfaction?

3. How does transformational leadership influence Organizational Citizenship Behavior?

4. How does the organizational climate affect Organizational Citizenship Behavior?

5. How does job satisfaction mediate the effects of transformational leadership and organizational climate on Organizational Citizenship Behavior?

Thus, it is necessary to further research the title Job Satisfaction as a Mediating Variable Between the Effects of Transformational Leadership and Organizational Climate on Organizational Citizenship Behavior (OCB) in the Regional Drinking Water of Cilacap Regency.

\section{Literature Review}

\subsection{Organizational Citizenship Behavior}

Organizational citizenship behavior explains that organizational citizenship behavior is free individual behavior that is not directly or explicitly recognized by the reward system and promotes the effective functioning of organizations [21]. The fundamental difference between in-role and extra-role behavior lies in the results obtained or awards. In-role behavior is usually associated with rewards and punishment (sanctions), while extra-role behavior is not associated with rewards to be received. Therefore, organizational citizenship behavior is a behavior related to individuals' personal choices who are members of the organization.

Seeing from several experts who revealed organizational behavior, we concluded that organizational citizenship behavior is a contribution. It could be given by employees in the company that is not directly related to their main tasks and can work together with others to increase the effectiveness in the organization [21].

There are five dimensions of organizational citizenship behavior proposed [15]. Those dimensions were:

a) Altruism

Employee behavior helps co-workers who experience difficulties in the current situation regarding tasks in the organization and other people's problems.

b) Conscientiousness

The behavior is shown by trying to exceed what is expected by the company. Voluntary behavior that is not an employee's duty or duty.

c) Sportsmanship

Behavior that tolerates less than ideal conditions in an organization without raising objections.

d) Courtesy

Courtesy was the behavior of maintaining good relations with colleagues to avoid interpersonal problems.

e) Civic Virtue

Civic Virtue was a behavior that indicates responsibility for organizational life. This dimension affects the organization's responsibility to a person to improve the quality of the previously occupied occupations. 


\subsection{Transformational Leadership}

Transformational leadership is the process by which people engage with others, and create relationships that promote motivation and morality in leaders and followers [22]. Real transformational leadership is a social and caring leadership with the common good. These transformational social leaders beat their interests for the good of others [22].

Transformational leadership is the leader who inspires his followers to transcend their interests and is capable of having a profound and extraordinary influence on his followers [21].

From the definitions exposed by the experts above, we concluded that transformational leadership is a leader who can inspire by motivating them so that their followers can achieve the organizational vision and mission objectives.

Indicators that affect the transformational leadership style [2] are:
a) High tolerance for uncertainty
b) Sustained energy
c) Passion of quality
d) Perseverance
e) Positive self - image
f) Credibility
g) Strong desire to influence others

\subsection{Organization Climate}

Organizational climate is the perception of organizational members (individually and in groups) and those [32]. They are closely related to organizations (e.g., suppliers, consumers, consultants, and contractors) regarding what is or is happening in the organization's internal environment and the performance of organizational members that then determine the performance of the organization [32].

The explanation of the organizational climate definition also defines that the organizational climate as a collection and pattern of the environment determines the emergence of motivation and focuses on perception - a sensible or can-rated perception so that it has a direct influence on the organizational member's performance [31]. With the organization's climate, the organization can improve the quality of work of its members. The organization's leadership openness (with all the ins and outs of the organization as a whole), the ability-based positioning and appeal of the leader for its members, is beneficial in advancing an organization.

There are dimensions and indicators of the organizational climate [33] :

a) State of the physical environment of the workplace.

b) State of the social environment.

c) Implementation of the management system.

d) Organization's member's physical and psychological conditions.

\subsection{Job Satisfaction}

Job satisfaction as a person's evaluation of his work and job context. It is an assessment of the characteristics of work, work environment, and emotional experience in the perceived work [32]. Job satisfaction also refers to a person's attitudes and feelings toward his job [20]. Job satisfaction will occur when the worker senses that the desired value is wanted is fulfilled [32]. The theory concerned with the fulfillment of the value is named value - percept theory. 
To measure job satisfaction according to the value - percept theory, we should assess several indicators [32]:
a) Satisfaction with the work itself.
b) Pay Satisfaction
c) Promotion Satisfaction
d) Supervision Satisfaction
e) Co-worker Satisfaction

\subsection{Research Model Development}

The research on sharia banking, shows that all components of transformational leadership affect job satisfaction [16]. Leadership with transformative reform encourages employees to be innovative $\&$ creative in such a way as to think beyond the boundaries and innovate new ideas, valuable to the organization. Also, concluded that the transformational leadership factors were able to explain the variation in subordinate satisfaction of 19.7 percent more than the leadership factors can explain [26]. Here are the hypotheses we can develop:

Hypothesis 1: Transformational Leadership affects Job Satisfaction.

The organizational climate in a company has a significant influence on the satisfaction of its employees' work so that leaders can create an appropriate organizational climate so that employees are satisfied in doing their job and have a high organizational [12]. Theresome research also tested the relationship between organizational climate, job satisfaction, and organizational commitment by examining the behavior of Thai technicians in the private sector of Thai telecommunications. Data analyzed by SEM Lisrel showed that the behavior of technicians depends on the climate of the organization to relate to the job satisfaction of the technician positively and also demonstrated that the organizational climate has an essential relationship to the work [5].

\section{Hypothesis 2: Organizational Climate affects Job Satisfaction.}

[1], [27] produced that transformational leadership has a significant effect on organizational citizenship behavior. [16] show that the transformational leadership style has a significant positive relationship with Organizational Citizenship Behaviour in the telecommunications sector in Pakistan. Job satisfaction should be a vital determinant of Organizational Citizenship Behavior [24].

Hypothesis 3: Transformational Leadership affects Organizational Citizenship Behavior.

Organizational citizenship behavior influenced by several factors mentions that the factors affecting behavior citizenship Organizational are organizational culture, organizational climate, personality and mood (mood), perception of organizational support, and quality of interactions [19]. Employees with high behavior citizenship organizational are also assessed to be able to be more innovative, provide the best service, and can create a pleasant atmosphere in the Organization [14].

Hypothesis 4: Organization Climate affects Organizational Citizenship Behavior.

The research conducted explains that there is a significant influence between job satisfaction on organizational citizenship behavior [13]. When employees are satisfied with their work, they will be able to have organizational behavior assisting the work of others and completing work beyond the level of employment given to him. Job satisfaction is positively related to behavior citizenship organizational, namely based on social exchange theory [10]. Employees do organizational citizenship behavior as a way to benefit their organization because it has created a pleasant or enjoyable work environment. Also, research in produces that job satisfaction is positively significant positively to behavior citizenship organizational $[7]$. 
Both intrinsic work satisfaction and extrinsic work satisfaction have a significant positive effect on Organizational Citizenship Behaviour [30]. Satisfaction felt by employees who come from salary, promotion, Suppervisi, co-worker, or the work he/she performed will increase Organizational Citizenship Behaviour.

\section{Hypothesis 5: Job Satisfaction affects Organizational Citizenship Behaviour.}

In this research, job satisfaction was included as an intervening variable in the model. So, the transformation style of transformational leadership and organizational climate will relate and affect job satisfaction. When employees are satisfied, they will want to do something that exceeds their work. Thus, the research hypothesized that the transformational leadership style and the organizational climate have an indirect effect on organizational citizenship behavior, through job satisfaction.

Hypothesis 6: Job satisfaction can be a mediating variable of the influence of organizational climate on Organizational Citizenship Behavior.

Hypothesis 7: Job satisfaction can be a mediating variable of the influence of transformational leadership on Organizational Citizenship Behavior.

Based on the hypothesis described above, the research model that will be further tested in this research is shown below:

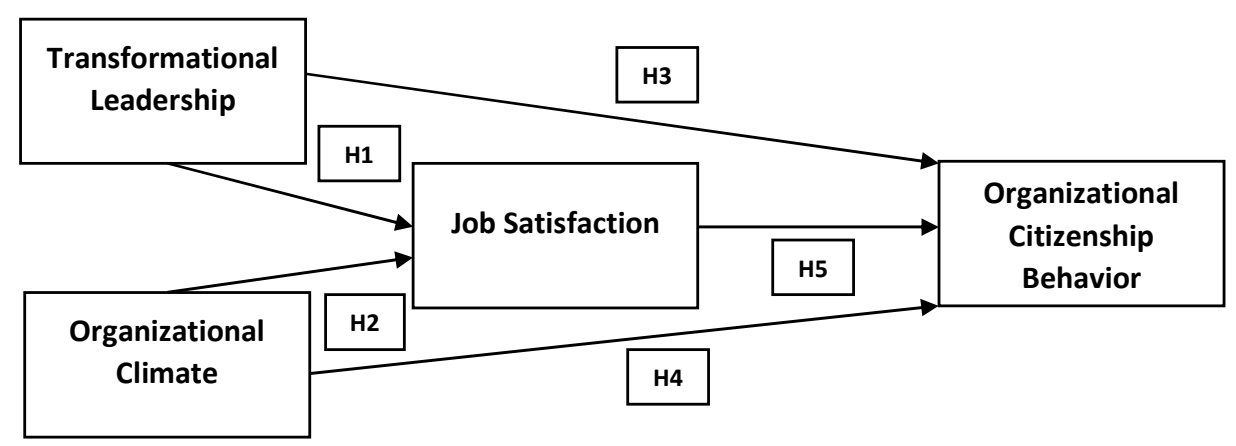

Fig.1. Research Thinking Framework Scheme

\section{Method}

\subsection{Research Methods}

a) Research Object

The object of this research is the employees of Regional Drinking Water Tirta Wijaya Cilacap Regency.

b) Types Of Research

This research is survey research, which gathers information about a group of people in which a direct relationship with objects studied by individuals, organizations, and society through systematic means, such as filling out questionnaires and interviews. 
c) Population

The population in this research were employees of Regional Drinking Water Tirta Wijaya Cilacap Regency, with a total of 219 employees in the Regional Drinking Water in May 2019 with details of 3 directors, 196 permanent employees, seven permanent employees, and 13 contract employees.

d) Sample

Based on the type of sampling technique, this research uses a non-probability sampling research using a purposive sampling approach with only permanent employees. It does not include leaders in the respondent. From these considerations, a sample of 131 employees was determined.

\section{Results And Discussion}

\subsection{Validity And Reliability Test Results}

a) Validity Test

In this research, the significance test was carried out by comparing the $r$ count of the $r$ table for the degree of freedom $(\mathrm{df})=\mathrm{n}-2(131-2=129)$, so that 0.1716 was obtained. All of the four variables studied were declared valid because the calculated r-value of these four variables is greater than the $\mathrm{r}$ table $(0.176)$.

b) Reliability Test

In the Cronbach's Alpha Reliability test of the four variables $>60$. The value stated that a questionnaire is reliable if one's answer to the statement is consistent or stable over time and can be reliable because of the Cronbach's Alpha value on all variables $>0.70$ [15]

\section{Model 1}

1. Classic Assumption Test

a) Normality Test

Based on the SPSS output of the Kolmogorov Smirnov test, the asymptotic sig value of 0.200 can be concluded that the unstandardized residual data is normally distributed because the asymptotic is significantly more than 0.05 .

b) Multicollinearity Test

In this research, a regression model is said to be free of multicollinearity if it has a VIF $<10$ and has a tolerance number $>0.10$.

Table 1. Multicollinearity Test Result

\begin{tabular}{cccc}
\hline & Collinerity Statistics & \\
\hline Variabel & Tolerance & VIF & Description \\
Transformational Leadership &, 664 & 1,507 & Free of Multicollinearity \\
Organizational Climate &, 664 & 1,507 & Free of Multicollinearity \\
\hline
\end{tabular}

It can be seen that the results of the calculation of the tolerance value indicate there is no independent variable that has a tolerance value of $\leq 0.10$, which means there is no correlation between the independent variables. While the results of the calculation of VIF values also show that there is no independent variable that has a VIF value $\geq 10$. So it can be concluded that there is no multicollinearity between the independent variables in the regression model. 
c) Heteroscedasticity Test

By regressing the independent variable to the absolute value of the residual (the Glejser method), the data is declared free from Heteroscedasticity assumptions, if the regression results show a significance value of $>(0.05)$. From the test results, we obtained that the significance value of the transformational leadership variable is 0.823 . The significant value of the organizational climate variable is 0.601 . From these results, it is said that the significant values of all variables $>0.05$. Thus, it can be interpreted that the regression model is free from heteroscedasticity because of the significant value $>0.05$.

d) Regression Test

1. Multiple Linear Regression Analysis

Multiple linear regression test aims to determine how much the influence of transformational and organizational climate on job satisfaction can be done with multiple linear regression tests. The results of multiple linear regression tests can be seen in the following table:

Table 2. Multiple Linear Regression Analysis Results Coefficients ${ }^{\mathrm{a}}$

\begin{tabular}{|c|c|c|c|c|c|c|c|c|}
\hline & \multirow[t]{2}{*}{ Model } & \multicolumn{2}{|c|}{$\begin{array}{c}\text { Unstandardized } \\
\text { Coefficients }\end{array}$} & \multirow{2}{*}{$\begin{array}{c}\text { Standardized } \\
\text { Coefficients } \\
\text { Beta } \\
\end{array}$} & \multirow[t]{2}{*}{$\mathrm{T}$} & \multirow[t]{2}{*}{ Sig. } & \multicolumn{2}{|c|}{$\begin{array}{c}\text { Collinearity } \\
\text { Statistics }\end{array}$} \\
\hline & & $\mathrm{B}$ & Std. Error & & & & Tolerance & VIF \\
\hline \multirow{3}{*}{1} & (Constant) &,- 024 &, 330 & &,- 072 & ,943 & & \\
\hline & TRS_LEAD &, 381 & 082 & ,350 & 4,670 &, 000 & 664 & 1,507 \\
\hline & ORG CLM &, 597 & 097 & ,463 & 6,178 &, 000 &, 664 & 1,507 \\
\hline
\end{tabular}

Based on the results of the regression analysis above, a regression equation can be arranged as follows:

$\mathrm{Y}=\alpha+\beta 1 \mathrm{X} 1+\beta 2 \mathrm{X} 2+\mathrm{e}$

$\mathrm{Y}=-0.024+0.381 \mathrm{X} 1+0.597 \mathrm{X} 2+\mathrm{e}$

The interpretations of the equation are:

$\alpha=-0.024$ means that based on the regression equation, it can be seen that if the independent variable (transformational leadership, organizational climate) does not change, job satisfaction is -0.024 units.

$\beta 1=0.381$ means that every time there is a one-unit increase in transformational leadership, there will be an increase in transformational leadership of 0.381 units if the other independent variables (transformational leadership, organizational climate) remain.

$\beta 2=0.597$ means that every time there is a one-unit increase in organizational climate, there will be an increase in organizational climate by 0.331 units if the independent variable (transformational leadership, organizational climate) the other remains.

$\mathrm{e}=$ Standard error (error).

2. Determination Test

The adjusted R-square value of the regression model formed in this research is 0.516 , which indicates that the independent variable (transformational leadership, organizational climate) in explaining the dependent variable (job satisfaction) is $51.6 \%$, the remaining $48.4 \%$ is explained by other variables not included in this research. 
Based on the results of the regression analysis above, a regression equation can be drawn up as follows:

$$
\begin{aligned}
& \mathrm{Y}=\alpha+\beta 1 \mathrm{X} 1+\beta 2 \mathrm{X} 2+\mathrm{e} \\
& \mathrm{Y}=-0,024+0,381 \mathrm{X} 1+0,597 \mathrm{X} 2+\mathrm{e}
\end{aligned}
$$

2. Hypothesis Test

a) F-Test (Simultaneous)

The ANOVA Test's value of fcount $>$ f-table is $70.379>2.74$, with a significance level of 0,000 . Because the probability $(0,000)$ is much smaller than 0.05 , the $\mathrm{f}$ test regression model can be used to predict job satisfaction.

b) T-Test (Partial)

To partially test the effect of transformational leadership on job satisfaction using ttable. T-test results that the transformational leadership variable has a t-count of 4.670 is higher than the t-table value of 2.365 and has a significant value of 0,000 . Because the significant value $<0.05$ and tcount $>t$ table $(4.670>2.365)$ means that there is a partial influence between transformational leadership and job satisfaction, so the hypothesis is accepted, and Ho is rejected. It is in line which states that transformational leadership has a significant effect on job satisfaction in Islamic banking in Pakistan [16]. To partially test the influence of organizational climate on job satisfaction using t-table. T-test results that the organizational climate variable has a t-count of 6.178 higher than the t table value of 2.365 and has a significant value of 0,000 . Because the significant value $<0.05$ and tcount $>t$ table $(6.178>2.365)$ means that there is a partial influence between organizational climate and job satisfaction, so the hypothesis is accepted, and Ho is rejected. This research is also in line with states that organizational climate has a significant effect on job satisfaction [12].

\section{Model 2}

1. Classic Assumption Test

a) Normality Test

Based on the SPSS output of the Kolmogorov Smirnov test, the asymptotic sig value is 0.925 ; it can be concluded that the unstandardized residual data is usually distributed because the asymptotic significance is more than 0.05 .

b) Multicollinearity Test

In this research, a regression model is said to be free of multicollinearity if it has a VIF $<10$ and has a tolerance number $>0.10$.

Table 3. Multicollinearity Test Results

\begin{tabular}{lrrl}
\hline & \multicolumn{3}{c}{ Collinerity Statistics } \\
\hline Variable & Tolerance & \multicolumn{1}{c}{ VIF } & Keterangan \\
Transformational leadership &, 567 & 1,763 & Free of Multicollinearity \\
Organizational Climate &, 511 & 1,956 & Free of Multicollinearity \\
Job Satisfaction &, 476 & 2,100 & Free of Multicollinearity \\
\hline
\end{tabular}

It can be seen that the results of the calculation of the tolerance value indicate there is no independent variable that has a tolerance value of $\leq 0.10$, which means there is no correlation between the independent variables. While the results of the calculation of VIF values also show that there is no independent variable that has a VIF value $\geq 10$. So it can be concluded that there is no multicollinearity between the independent variables in the regression model. 
c) Heteroscedasticity Test

By regressing the independent variable to the absolute value of the residual (the Glejser method), the data is declared free from Heteroscedasticity assumptions, if the regression results show a significance value of $>(0.05)$. From the test results obtained that the significance value of the transformational leadership variable is 0565 , the significant value of the organizational climate variable is 0.430 . The significant value of the job satisfaction variable is 0.338 . From these results, it is said that the significant values of all variables $>0.05$. Thus, it can be interpreted that the regression model is free from heteroscedasticity because of the significant value $>0.05$.

\section{d) Regression Test}

1. Multiple Linear Regression Analysis

Multiple linear regression test aims to find out how much influence the transformational organizational climate and job satisfaction on Organizational can be done with multiple linear regression tests. The results of multiple linear regression tests can be seen in the following table:

Table 4. Multiple Linear Regression Analysis Results

\begin{tabular}{|c|c|c|c|c|c|c|}
\hline \multicolumn{7}{|c|}{ Coefficients $^{\mathrm{a}}$} \\
\hline \multirow{3}{*}{\multicolumn{2}{|c|}{ Model }} & \multirow{2}{*}{\multicolumn{2}{|c|}{$\begin{array}{c}\text { Unstandardized } \\
\text { Coefficients }\end{array}$}} & \multirow{3}{*}{$\begin{array}{l}\text { Standardized } \\
\text { Coefficients } \\
\text { Beta }\end{array}$} & \multirow[t]{3}{*}{$\mathrm{t}$} & \multirow{3}{*}{ Sig. } \\
\hline & & & & & & \\
\hline & & B & Std. Error & & & \\
\hline & (Constant) & ,597 & ,322 & & 1,854 & ,066 \\
\hline \multirow{3}{*}{1} & TRS_LEAD &, 173 & ,086 & , 165 & 2,006 &, 047 \\
\hline & ORG_CLM & ,414 & , 108 & ,333 & 3,845 &, 000 \\
\hline & JOB_SAT & ,308 & ,086 & ,321 & 3,570 &, 001 \\
\hline
\end{tabular}

a. Dependent Variable: ORGANIZATIONAL CITIZENSHIP BEHAVIOUR

Based on the results of the regression analysis above, a regression equation can be arranged as follows:

$\mathrm{Y}=\alpha+\beta 1 \mathrm{X} 1+\beta 2 \mathrm{X} 2+\beta 3 \mathrm{X} 3+\mathrm{e}$

$\mathrm{Y}=-0.597+0.173 \mathrm{X} 1+0.414 \mathrm{X} 2+0.308 \mathrm{X} 3+\mathrm{e}$

The interpretations of the equation are:

$\alpha=0.597$ means that based on the regression equation, it can be seen that if the independent variable (transformational leadership, organizational climate, job satisfaction) does not change the organizational citizenship behavior of 0.597 units.

$\beta 1=0.173$ means that every time there is an increase per one unit of transformational leadership, there will be an increase in transformational leadership of 0.173 units if the independent variables (transformational leadership, organizational climate, job satisfaction) remain the same.

$\beta 2=0.414$ means that every time there is an increase in organizational climate per one unit, there will be an increase in organizational climate by 0.414 units if the independent 
variables (transformational leadership, organizational climate, job satisfaction) remain the same.

$\beta 2=0.308$ means that every time there is an increase in job satisfaction, there will be an increase in job satisfaction by 0.308 units if the independent variables (transformational leadership, organizational climate, job satisfaction) remain the same.

e $=$ Standard error (error).

2. Determination Test

The adjusted R-square value of the regression model formed in this research is 0.501 , which shows that the independent variable (transformational leadership, organizational climate, and job satisfaction) could explain the dependent variable (organizational citizenship behavior) $50.1 \%$. The rest that equal to $49.9 \%$ is explained by other variables not included in this research.

\section{Hypothesis Test}

a) F-Test (Simultaneous)

From the ANOVA Test, the value of fcount $>$ f-table is $44.474>2.74$, with a significance level of 0,000 . Because the probability $(0,000)$ is much smaller than 0.05 , the f test regression model can be used to predict organizational citizenship behavior.

b) T-Test (Partial)

To partially test the effect of transformational leadership on organizational citizenship behavior using t-table. T-test results that the transformational leadership variable has a t-count of 2.006 is higher than the t-table value of 1.995 and has a significant value of 0.047 . Because the significant value $<0.05$ and tcount $>\mathrm{t}$ table $(2.006>1.995)$ means that there is a partial influence between transformational leadership and organizational citizenship behavior, so the hypothesis is accepted, and Ho is rejected. It is consistent with research conducted [16] that showed that transformational leadership style has a significant positive relationship on organizational citizenship behavior in the telecommunications sector in Pakistan. To partially examine the influence of organizational climate on organizational citizenship behavior, using the $t$ table. T-test results that the organizational climate variable has a t-count of 3.845 greater than the table value of 1.995 and has a significant value of 0,000 . Because the significant value $<0.05$ and tcount $>$ t-table $(3.845>1.995)$ means that there is a partial influence between organizational climate and Organizational Citizenship Behavior, so the hypothesis is accepted, and Ho is rejected. This research is also in line with research conducted [19], which states that one of the factors that influence organizational citizenship behavior is the organizational climate. To partially test the effect of job satisfaction on organizational citizenship behavior using the $t$ table. T-test results that the variable job satisfaction has a t-value of 3.570 is greater than the value of t-table of 1.995 and has a significant value of 0.001 . Because the significant value $<0.05$ and tcount $>$ t-table $(3.570>$ 1.995) means that there is a partial influence between job satisfaction with Organizational Citizenship Behavior, so the hypothesis is accepted, and Ho is rejected. This research is also in line with explains that there is a significant influence between job satisfaction on organizational citizenship behavior [13].

\subsection{Sobel Test}

Test Mediation hypothesis testing can be done by a procedure developed by Sobel (1982) in (Ghozali, 2015) known as the Sobel Test. Sobel test is done by testing the strength of the 
indirect effect of the independent variable $(X)$ to the dependent variable $(Z)$ through intervening (Y). Based on the Sobel test calculator located on the web https://www.danielsoper.com/statcalc/calculator.aspx?id=31 we obtained statistical data as follows:

Table 5. Sobel Test Result

\begin{tabular}{cc}
\multicolumn{2}{c}{ Table 5. Sobel Test Result } \\
\hline Sobel Test Statistic & 3,09546066 \\
One - Tail Probability & 0,00098254 \\
Two - Tail Probability & 0,00196507 \\
\hline
\end{tabular}

With $\alpha 0.05$ of $=\alpha \pm 1.995$, it can be seen that the Sobel Test Statistic $>\alpha(3.09546066>\alpha)$ where the Sobel test is in the Ha reception area. These results explain that job satisfaction can be a mediating variable to the influence of transformational leadership and organizational climate on organizational citizenship behavior.

\section{Conclusion}

Based on data analysis and discussion that has been done, it can be concluded that all hypotheses are accepted, and job satisfaction variables can be a mediation between the influence of transformational leadership and organizational climate on organizational citizenship behavior.

Based on the results of the research there are some suggestions for company improvement and researchers in the future Regional Drinking Water Tirta Wijaya is expected to be able to further improve the transformational leadership variable where leaders must be more able to create enthusiasm for employees, get closer, and create a good relationship between hierarchy of leaders - leaders so that there is important information to employees more accurately, company leaders are expected to create a better organizational climate as in the assignment carried out by the company should not be too frequent because frequent transfer of employee assignments to branches or other units will require again an adaptation for employees, giving compensation not only in the form of financial but also provides nonfinancial satisfaction such as recognition, and appreciation of employee work achievements for example by including a model employee so that employees feel proud and other employees' motivation to work better is another, it will indirectly increase employee job satisfaction and influence the behavior of the organizational citizenship behavior of employees.

\section{References}

[1] Amalia dan Veneta (2018). Pengaruh Kepemimpinan Transformasional Organisasi Terhadap Organizational Citizenship Behaviour. Jurnal Riset Bisnis dan Investasi.

[2] Ali. 2012. Kepemimpinan Transformasional dalam Birokrasi Pemerintahan. Jakarta ; PT. Multicerdas Publishing.

[3] Astina, I. N. G., \& Sriathi, A. A. A. (2016). Pengaruh Gaya Kepemimpinan Dan Iklim Organisasi Terhadap Kepuasan Kerja Karyawan Di Pt. Billabong Indonesia. E-Jurnal Manajemen, 5(5). https://ojs.unud.ac.id/index.php/Manajemen/article/view/20103.

[4] Bass, B.M. 1997. Does Transactional - Transformational Leadership Paradigm Transcend Organizational and National Boundaries? Journal American Psychologist, 52: 130-139. 
[5] Bhaesajsanguan S. 2010. The Relationships among Organizational Climate, Job Satisfaction and Organizational Commitment in the Thai Telecommunication Industry. E-Leader Singapore Journal. 10: 1-15.

[6] Bienstock, C.C., DeMoranville, C.W., dan Smith, R.K. 2003. Organizational Citizenship Behavior and Service Quality. Journal of Services Marketing, Vol 17 No. 4, 2003 pp. 357-378.

[7] Bodroastuti, t., \& Ruliaji, a. (2016). "Pengaruh komitmen organisasi dan kepuasan kerja terhadap Organizational Citizenship Behaviour (Organizational Citizenship Behaviour) serta dampaknya terhadap kinerja karyawan”. Jurnal dinamika ekonomi \& bisnis, 13(1).

[8] Brahmana, S. Sunardi dan Sofyandi, Herman (2007). Transformational Leadership dan Organizational Citizenship Behaviour Di Utama. Laporan Penelitian Kelompok. Fakultas Bisnis dan Manajemen. Universitas Widyatama, 2007.

[9] Castro ML, Martin N. 2010. The Relationship Between Organisational Climate and Employee Satisfaction in A South Africa Information and Technology Organisation. SA Journal of Industrial Psychology. 36:1-9.

[10] Cropanzano, R., Howes, J.C., Grandey, A.A., \& Toth,P., (1997). "The Relationship Of Organizational Politics and Support to Work Behaviors, Attitudes, and Stress". Journal of Organizational Behavior, 18, hal. 159-180.

[11] Dotulong, Lengkong dan Wongkar. 2018.Pengaruh Kepemimpinan Transformasional Dan Iklim Organisasi Terhadap Organizational Citizenship Behaviour (ORGANIZATIONAL CITIZENSHIP BEHAVIOUR) Pada Dinas Pendidikan Daerah Provinsi Sulawesi Utara.Jurnal EMBA.

[12] Danish et al. - 2015-Impact of Organizational Climate on Job Satisfacti.pdf. (n.d.). Retrieved May 6,2020 , from

https://www.researchgate.net/profile/Rizwan_Danish2/publication/280840587_Impact_of_Organiz ational_Climate_on_Job_Satisfaction_and_Organizational_Commitment_in_Education_Sector_of Pakistan/links/55c8fd3508aeca747d $\overline{6} 70 \mathrm{~b} 7 \mathrm{~d}$.pdf.

[13] Ferdus, Zannatul, and Thawhidul Kabir. 2018. "Effect of Job Satisfaction and Organizational Commitment on OCB: Research on Private Banks in Bangladesh." World Journal of Social Sciences 8 (2): 57-69.

[14] Gholami, S., Keykale, M., Tir, M., Ramandi, F., Karimi, M., \& Rajaee, R. (2015). Investigating the relationship between organizational climate and organizational citizenship behavior among staff hospital. European Journal of Biology and Medical Science Research, 3(3), 54-63.

[15] Ghozali. 2015. Aplikasi Analisis Multivariete. Semarang; Badan Penerbit Universitas Diponegoro.

[16] Malik, S. Z.., M. Saleem and R. Naheem. (2016). Effect of Leadership Style on Organizational Citizenship Behaviourin Employee of Telecom Sector in Pakistan. Economic and Social Review, 54(2). 385-406.

[17] Organ, D.W., Podsakof, M.P., MacKenzie, B.S. 2006. Organizational Citizenship Behavior. USA : Sage Publications, Inc.

[18] Podsakoff, P. M., et al. 2000. Organizational Citizenship Behavior: A Critical Review of The Theoretical and Empirical Literature and Suggestions for Future Research. Journal of Management, Vol. 26, No. 3.

[19] Lubis. M Saleh. 2015. Pengaruh Iklim Organisasi Dan Komitmen Organisasi Terhadap Pembentukan Organizational Citizenship Behavior (OCB) Karyawan Dalam Rangka Peningkatan Kinerja. E-Jurnal Apresiasi Ekonomi Volume 3, Nomor 2. Sekolah tinggi Ilmu Ekonomi (STIE) Pasaman, Simpang Empat.

[20] Lestariningtyas. 2016. Peran komitmen organisasi sebagai variabel intervening antara kepuasan kerja dan Organizational Citizenship Behavior (OCB) pada karyawan PT. Coca-Cola distribution Indonesia Surabaya. Jurnal Ilmu Manajemen. 4(3).

[21] Napitupulu, D. (2018, Edisi I Januari - Juni ). Pengaruh kepemimpinan transformasional dan komitmen organisasi terhadap organizational citizenship behavior (ocb) (studi pada perawat rumah sakit puri husada di tembilahan). Jom Fisip, 5.

[22] Northouse. 2016. Kepemimpinan. Jakarta;Permata Putri Media.

[23] Robbins, Stephen P. 2001. Perilaku Organisasi: Konsep, Kontroversi, Aplikasi, Jilid 1, Edisi 8, Prenhallindo, Jakarta. 
[24] Robbins, Stephen P.,T.A. Judge. 2015. Perilaku Organisasi edisi 16. Jakarta: Salemba empat.

[25] Robbins. Stephen. P.judge. Thimoty.2013. Perilaku Organisasi. Jakarta; Salemba.

[26] Rokhman, W. dan Harsono. 2002. Peningkatan Pengaruh Kepemimpinan Transformasional Terhadap Kepemimpinan Transaksional Pada Komitmen Organisasi dan Kepuasan Bawahan, Journal Empirilks, Vol. 11, No. 1, Juni 2002

[27] Rianto.2017. Pengaruh Kepemimpinan Transformasional Dan Komitmen Organisasi Terhadap Organizational Citizenship Behaviour Perawat Rawat Inap Pada Rumah Sakit Eka Hospital Pekanbaru. JOM Fekon Vol.4.

[28] Rukhana. 2016. Pengaruh Kepemimpinan Transformasional Terhadap Organizational Citizenship Behaviour Pada Tenaga Perawat RSUD Dr. Saiful Anwar Malang. Jurnal Administrasi Bisnis(JA) Vol.33

[29] Sabahi and Sanai Dashti - 2016 - The effect of emotional intelligence and job satis.pdf. (n.d.). Retrieved May 5, 2020, from http://www.growingscience.com/msl/Vol6/msl_2016_34.pdf

[30] Sudibya, I. G. A., Putra,I. P. A. K. 2018. Pengaruh Kepuasan Kerja, Komitmen Organisasional Dan Motivasi Kerja Terhadap Organizational Citizenship Behavior. E-Jurnal Manajemen Unud, Vol. 7, No. 8, 2018: 4447-4474.

[31] Stringer, Robert. 2002. Leadership and Organizational Climate: The Cloud Chamber Effect. New Jersey: Prentice Hall

[32] Wibowo. 2015. Perilaku Dalam Organisasi. Depok; PT RajaGrafindo Persada.

[33] Wirawan 2007. Budaya dan Iklim Organisasi. Jakarta : Salemba Empat 